\title{
炭素材料のラマンスペクトルおよびその新しい応用
}

\author{
片桐 元
}

(平成 8 年 10 月 7 日)

\section{Raman Spectroscopy of Graphite and Carbon Materials and Its Recent Application}

\author{
Gen Katagiri \\ Toray Research Center, Inc., \\ 3-7 Sonoyama 3-chome, Otsu, Shiga 520, Japan
}

\begin{abstract}
Recent study of the Raman spectroscopy for graphite and carbon materials were reviewed, including the explanation for the structural-sensitive spectrum, the results of the measurements with very high signal-to-noise ratio, the excitation wavelength dependence, the method for the characterization of texture and microstructure and the Raman microprobe application. Some issues were also pointed out to utilize the structural-sensitive Raman spectroscopy to characterization of a variety of carbon materials.
\end{abstract}

\section{1. はじめに}

さまざまな炭素材料の評価手法として,レーザーラマン分 光法が一般的に用いられるようになってきた。本誌に扔いて は20年ほど前に中溝によって講座「ラマン分光」1が解説 されている。その内容は現在でも十分に通用する意義深いも のであるが，その後 20 年の間にさまざまな炭素材料のラマ ンスペクトルについての測定結果が報告され，基礎的研究， 評価応用のいずれにおいても大きな進展が認められている。 一方，ラマンスペクトルの測定装置についても CCD 検出器, ホログラフィックノッチフィルターとシングルモノクロメ 一夕の組み合わせによって著しい高感度化が達成され，質の 良いスペクトルを短時間で得ることができるようになった。 本稿では，炭素材料のラマンスペクトルに関する最近の状況 および未解決の問題などについて筆者らの研究結果を中心 に紹介し，ラマンスペクトルからどのような構造情報を引き 出すことができるかについて解説したい。

\section{2. グラファイトのラマンスペクトル}

完全な構造を有するグラファイトの結晶構造（D ${ }^{4} 6 \mathrm{~h} ）$ か
ら期待される振動モードは，

$$
\Gamma=\mathrm{A}_{2 \mathrm{u}}(\mathrm{IR})+2 \mathrm{~B}_{2 \mathrm{~g}}+\mathrm{E}_{1 \mathrm{u}}(\mathrm{IR})+2 \mathrm{E}_{2 \mathrm{~g}}(\mathrm{R})
$$

であり2)，2本のラマン活性 $\left(2 \mathrm{E}_{2 \mathrm{~g}}\right)$ および2本のIR 活性 $\left(A_{2 u}, E_{1 u}\right)$ な振動モードが存在する。これらの振動モード は, Fig.1に示すHOPGのラマンスペクトル $\left(2 \mathrm{E}_{2 \mathrm{~g}} ： 1581\right.$ および $\left.42 \mathrm{~cm}^{-1}\right)$ 3) および赤外反射スペクトル $\left(\mathrm{A}_{2 \mathrm{u}}\right.$ ： $\left.1588 \mathrm{~cm}^{-1}, \mathrm{E}_{1 \mathrm{u}} ： 868 \mathrm{~cm}^{-1}\right)$ 4)に扔いて実際に見出されてい る。これらのうち， $\mathrm{A}_{2 \mathrm{u}}$ のみはグラファイト層面に垂直な方 向に成分を有する面外モードであるが，他の3つはいずれ も面内モードである。

結晶サイズ $\left(\mathrm{L}_{\mathrm{a}}\right)$ の異なるグラファイトの1次および2次 の領域に扩けるラマンスペクトルを Fig.2に示す。グラファ イト構造に乱れが生じると, $1580 \mathrm{~cm}^{-1}$ のラマンバンドの他 に1360 および $1620 \mathrm{~cm}^{-1}$ にラマンバンドが認められるよう になり，構造の乱れが大きくなるとともにこれらのバンド の $1580 \mathrm{~cm}^{-1}$ のラマンバンドに対する相対強度が増し，全体 にブロードなバンド形状となってゅくことは良く知られて いる。1360および $1620 \mathrm{~cm}^{-1}$ のバンドは構造の乱れ（Disorder）に起因するものとして, グラファイト（Graphite）本 

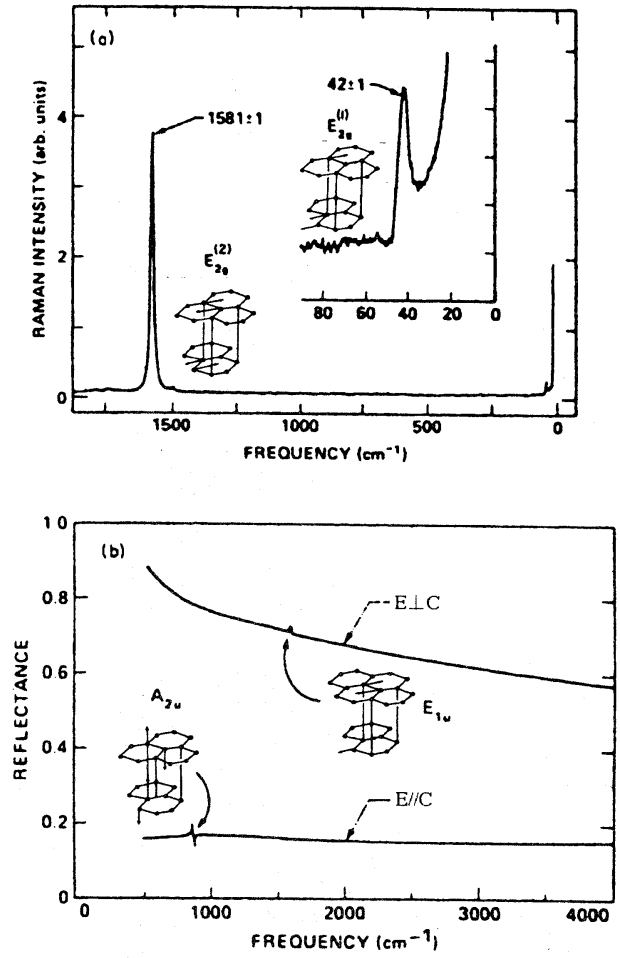

Fig.1 (a) Raman and (b) infrared reflectance spectra of HOPG.

来の $\mathrm{G}$ バンド $\left(1580 \mathrm{~cm}^{-1}\right)$ に対して, Dバンド $\left(1360 \mathrm{~cm}^{-1}\right)$ やD'バンド $\left(1620 \mathrm{~cm}^{-1}\right)$ と略称されている。このようにグ ラファイトのラマンスペクトルは他の化合物には例がない ほど構造欠陥に対して著しく敏感であり，炭素材料の評価 手法として有用であることはもちろん, ラマン分光法自体 を研究対象とする立場からも非常に興味深い。

そのようなわけで, 炭素材料のラマンスペクトルと言えば $\mathrm{R}$ 值と呼ばれる2つのラマンバンドの強度比 $\left(\mathrm{I}_{1360} / \mathrm{I}_{1580}\right)$ によ る黒鉛化度の評価5)，6）が広く知られており，さまざまな炭 素材料の評価, 特許における規定のパラメータにしばしば用 いられている。しかしながら， R 值の意味するものはそれほ ど単純ではなく, 安易に用いれば誤った解釈を導くことにも なりかねない。 R 值を用いた評価の問題点を以下にまとめた。

(1) R 值は本質的に励起波長に依存する (後述)。

(2) ラマンスペクトルでは通常, 装置光学系 (検出器や分光 器)の分光感度特性の補正は行わないので, R 值は装置や測 定条件に依存する。特に, 特許などパラメータとして規定 する場合は装置，測定条件を明示するなど，細心の注意が 必要である。

(3) $\mathrm{R}$ 值はX線回折により求めた $\mathrm{La}$ と逆相関を示すと言わ れている5，6) が，極めて表面感度の高いラマンスペクトル

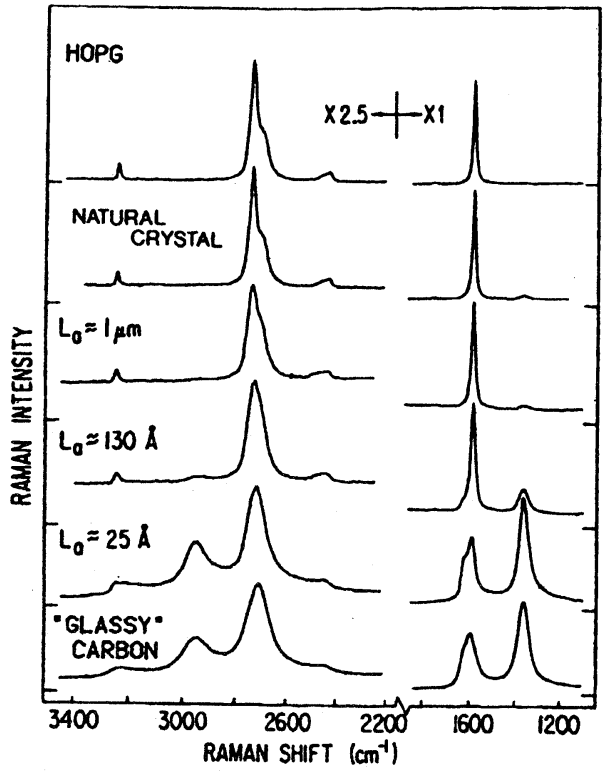

Fig.2 First- and second-order Raman spectra of graphite materials with different crystallite sizes, $\mathrm{L}_{\mathrm{a}}$.

とバルクを評価するX 線回折の結果を直接比較することに は注意を要する。特に, 炭素材料の場合は表面とバルクの 構造に差がある場合が多く，両手法の結果に対応が認めら れないことも多い。

(4) $\mathrm{R}$ 值と黒鉛化度の関係はある程度黒鉛化度の高いもの (一般的にはハードカーボンの場合の熱処理温度にしておよ そ2000 ${ }^{\circ} \mathrm{C}$ 以）について成り立つ。カーボンブラックなど のアモルファスなもの（熱処理温度にしておよそ $1000{ }^{\circ} \mathrm{C}$ $2000{ }^{\circ} \mathrm{C}$ 程度) は $\mathrm{R}$ 值の変化が極めて鈍感であり, さらには 熱処理温度にして $1000{ }^{\circ} \mathrm{C}$ 以下のカーボン, あるいは石炭や ピッチなどのラマンスペクトルは出発物質などさまざまな 要因に依存して極めて複雑な挙動を示し, 構造との関係を 一般化することが困難である12)。

さて, このような構造の乱れによるラマンスペクトルの

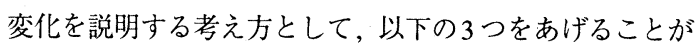
できる。

（1）結晶のエッジにおける全対称I モード5)

グラファイト構造に乱れが生ずることによって結晶サイ ズが有限となり，その結晶子の周辺の部分の対称性は無限 に拡がるグラファイト平面を有するグラファイト構造の場 合とは異なったものとなる。DバンドやD' バンドはこのよ うな対称性の低下によって, ラマン活性となった全対称

I 全対称モード：振動の変位のすべての状態において平衡位置に おける対称性が保たれる振動モード。 


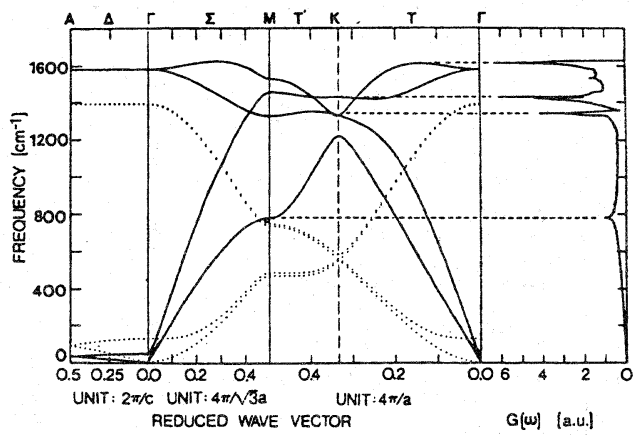

Fig.3 Phonon dispersion curves obtained for in-plane $(-)$ and out-of-plane $(\cdots)$ modes of graphite. The calculated density of states, G $(\omega)$ can reproduce Raman spectrum of disordered graphite.

$\left(\mathrm{A}_{\mathrm{g}}\right)$ モードによる。この考え方はグラファイトのラマンス ペクトルに関する論文を最初に発表したTuinstra と Koenig ${ }^{5)}$ によるものであり，広く知れわたったものである。この考 え方は後述するエッジ面のラマンスペクトルもうまく説明 することができる。

(2) 波数ベクトル選択則のくずれによる分散曲線の特異点 の寄与7：9)

結晶のラマン散乱は運動量保存則の制約から, フォノン のエネルギー $(\mathrm{E})$ と波数ベクトル $(\mathrm{k})$ の間の分散関係に おける $\mathrm{k}=0$ の点においてのみ生ずるが, 構造の乱れによっ てこのラマン散乱における波数ベクトルの選択則（ $\mathrm{k}=0)$ が破れ，ラマン散乱はBrillouin zoneの全領域から生ずる ようになる。Fig.3にグラファイトの面内の振動モードにつ いての分散曲線とそれより計算した振動の状態密度を示し た。なお，点線は面外の振動モードについての分散曲線で あるが, 状態密度の計算は行っていない。このようなこと は結晶の非晶化に伴うラマンスペクトルの変化を考える上 では一般的なことであるが, 炭素材料において特徴的なこ とはFig.3に示すように分散曲線が極值や変曲点などの特 異点を有し，これらの部分における振動の状態密度が高く なってラマンバンドが観測されるようになるという点にあ る。このようなアプローチはNemanich ら7), Dresselhaus のグループ8，9)によってなされ，実測のラマンスペクトル と状態密度の計算の比較が行われている。この考え方は構 造の乱れに伴う $1360 \mathrm{~cm}^{-1}$ や $1620 \mathrm{~cm}^{-1}$ のバンドの出現を良 く再現し，さらにこれらの倍音である $2 \mathrm{D}\left(2720 \mathrm{~cm}^{-1}\right)$ およ び2D' $\left(3248 \mathrm{~cm}^{-1}\right)$ バンドが, 大きさが同じで方向が逆向 きの $2 つ の$ 波数べクトルの結合が $\mathrm{k}=0$ の選択則を満足する ため, 構造の乱れのないHOPGにおいても観測されること

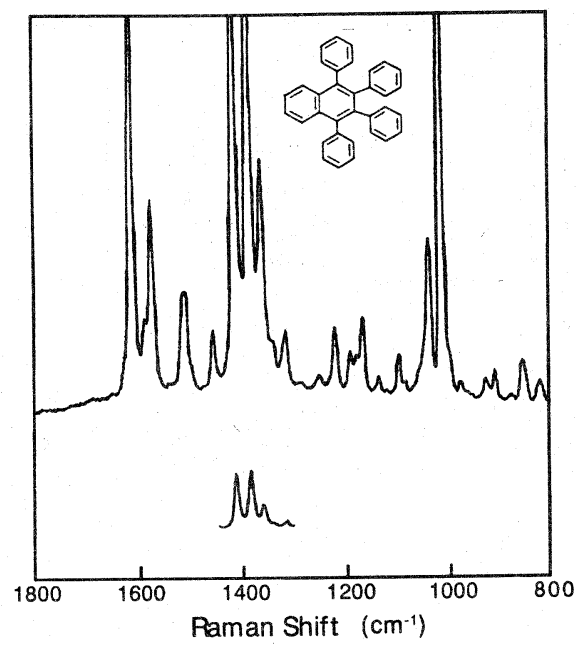

Fig.4 Raman spectrum of 1,2,3,4-tetraphenylnaphthalene.

をうまく説明することができる7)。

(3) 多環芳香族化合物の混合物 10)

炭素材料は多くの種類の多環芳香族化合物の混合物であ り，ラマンスペクトルもその各構成成分のラマンスペクト ルの重ね合わせになるという考え方である。このような考 え方はNakamizoら10)により提案されている。多くの多環 芳香族化合物では $1600 \mathrm{~cm}^{-1}$ 付近および $1300 \sim 1400 \mathrm{~cm}^{-1}$ 付 近に環の骨格振動による比較的強度の高いラマンバンドが 共通して認められる。前者は比較的純粋な環の $\mathrm{C}=\mathrm{C}$ 結合の 伸縮振動, 後者は環の呼吸振動济に対応するバンドである12)。 化合物によってラマンバンドの位置が異なるもののさまざ まな多環芳香族化合物の混合物では $1600 \mathrm{~cm}^{-1}$ および $1350 \mathrm{~cm}^{-1}$ 付近にブロードなバンドが認められるようになる わけである。Fig.4に1,2,3,4-tetraphenylnaphthalene のラ マンスペクトル11）を示す。モノ置換ベンゼン環に特有の $1000 \mathrm{~cm}^{-1}$ 付近のバンドを除くと, この段階ですでにカーボ ンを思わせるようなラマンスペクトルのパターンが認めら れることは注目に值する。石炭やピッチは実際に多くの種 類の多環芳香族化合物の混合物であり，そのラマンスペク トルにおいてはFig.5に示すような2本のブロードなバンド が認められることは，この考え方の妥当性を強く支持する ものである。多環芳香族化合物のラマンバンドの多くは全 対称モードであり, さらに共鳴ラマン効果顺にる強度の増

II 呼吸振動（breathing mode）：環全体か呼吸するように膨らん だり，縮んだりする振動。

III 共鳴ラマン効果 : ラマンスペクトルの測定に用いる光源の波長 が試料の吸収帯内にある場合に, 電子遷移との相互作用のため ラマン散乱強度が大きく増大する現象。 


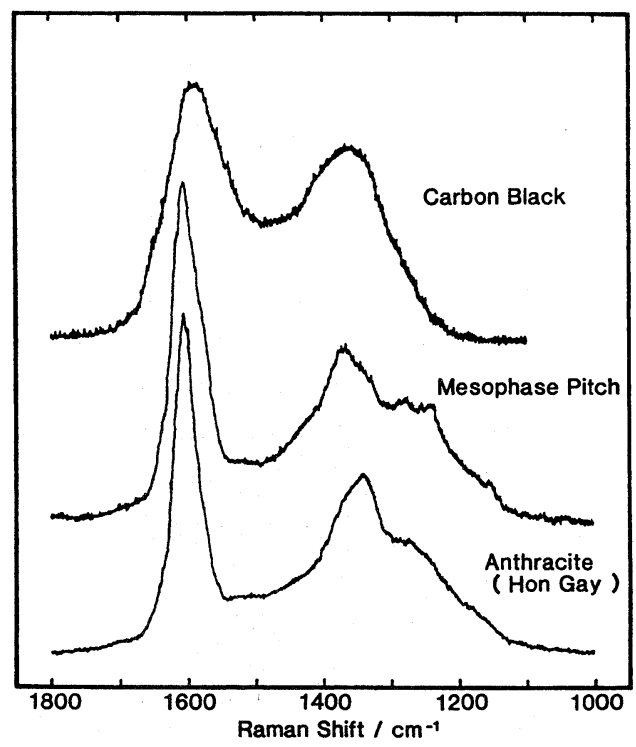

Fig.5 Raman spectra of amorphous carbon materials.

大を受けているものと考えられる12)。環全体が伸び縮みす る呼吸振動は環の縮合が大きくなるにつれて起こりにくく なり，環が無限に拡がったグラファイトではこのような振 動モードは結晶における並進対称性を满たさず禁制となる ため, $1360 \mathrm{~cm}^{-1}$ 付近のバンドが認められなくなると考える ことができる。一方, $1600 \mathrm{~cm}^{-1}$ 付近のバンドは対称性が高 まるにつれて全対称から $\mathrm{E}_{2 \mathrm{~g}}$ モードへと変化し, $1580 \mathrm{~cm}^{-1}$ 付近にシフトするものと考えられる。すなわち，この考え 方はグラファイトに近い領域では（1）の考え方の逆の状況 となる。

これら3つの考え方はいずれも炭素材料の複雑なラマン スペクトルをうまく説明できるものであり，どれかが正し くて，どれかか誤っているという性質のものではない。む しろ，これらの考え方をうまく組み合わせてこそ，より理 解を深めることができるのではないかと筆者は思っている。

\section{3. エッジ面のラマンスペクトル}

周知のようにグラファイトは異方性が高く, 䢃開によって 得られるベーサル面とこれに垂直なエッジ面が存在する。 Fig.6に熱分解黑鉛 (PG) の擘開したベーサル面および鏡面 研磨したエッジ面のラマンスペクトル13) を示す。エッジ面 では 1360 および $1620 \mathrm{~cm}^{-1}$ のバンドの $1580 \mathrm{~cm}^{-1}$ のラマンバ ンドに対する相対強度が増すが, $1580 \mathrm{~cm}^{-1}$ のラマンバンド の半值幅 $\left(\Delta v_{1580}\right)$ はほぼ同一の值を示す。当初，このよう なラマンスペクトルの変化は研磨による構造の乱れ14), 表 面酸化種の形成15) によるものと解釈されてきた。筆者ら 13)

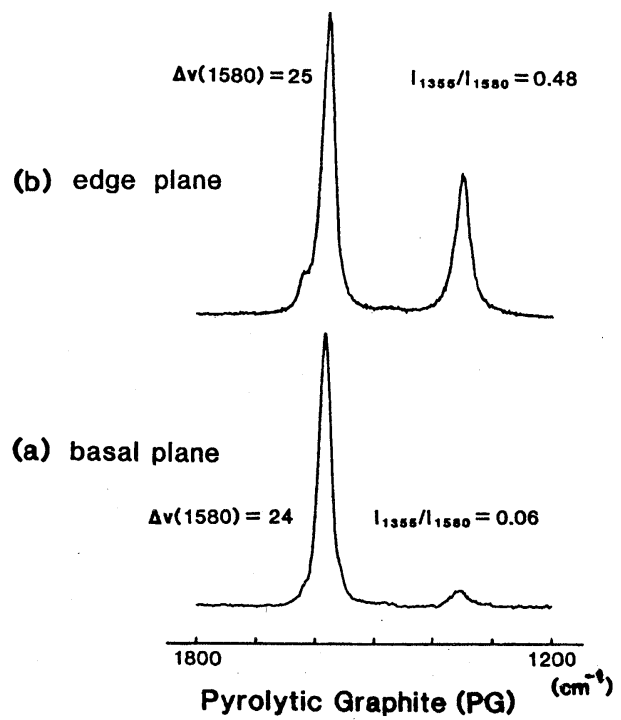

Fig.6 Raman spectra of cleaved basal plane and polished edge plane of pyrolytic graphite.

はPGのエッジ面について以下のような系統的な研究を行 い, ラマンバンドの強度, $\mathrm{I}_{1360} / \mathrm{I}_{1580}, \Delta \mathrm{v}_{1580}$ などを比較した。 (1)研磨の粗さの違い, 研磨面の熱処理など異なる条件で作 成したエッジ面の比較。

(2)グラファイトの層面に平行および垂直な偏光方向の比較。 (3)研磨の角度依存性。

これらの詳細な結果については省略するが，エッジ面で は無限に拡がるべきグラファイト平面が途切れてしまい, この部分でグラファイト本来の対称性が失われるため, 完 全なグラファイトでは禁制な 1360 や $1620 \mathrm{~cm}^{-1}$ のバンドの 相対強度が増すという解釈を行った13)。この結論はWang ら 16)によるHOPG のエッジ面についての同様な研究の結 果からも支持されている。すなわち, エッジ面では研磨の 不完全性による構造の乱れというよりも, 断面を出すこと によってグラファイト平面が途切れてしまうという必然的 に存在する構造の乱れ (対称性の低下) によってエッジ面 に特有のラマンスペクトルとなるわけである。これは, 前 節の（1）の考え方においてエッジ面全体が結晶の境界とな っていると考えれば極めて理解しやすい。

もちろん, エッジ面には研磨による構造の乱れも存在す るだろうし，酸素や水素などによって切れた結合が終端さ れているはずである。本当に構造の乱れが大きい場合には $\Delta v_{1580}$ が大きな值をとり，黒鉛化度の低下として表れる。ま た，ラマンスペクトルは残念ながらそれほど表面感度が高 くないし,グラファイトに比較すれば共鳴ラマン効果を受 けない最表面の官能基に対する検出感度は極めて低くなる。 
極端な例としてグラファイトの表面に何らかの物質を塗布 してラマンスペクトルを測定した場合, どの程度の厚さ塗 布すれば検出可能であるかを調べれば，この状況は容易に 理解が可能である。

\section{4. 励起波長依存性について}

グラファイトのラマンスペクトルが励起波長に依存する ことは1981年Vidanoら 17)によってはじめて報告され，そ の後いくつかのグループよって研究が行われてきた16)，1820)。これらの結果においては, 炭素材料の種類によらずグ ラファイトからグラッシーカーボンに至るまで, 励起波長 を長くすると, $1580 \mathrm{~cm}^{-1}$ 付近の $\mathrm{G}$ バンドには大きな変化が 認められないが, $1360 \mathrm{~cm}^{-1}$ 付近のDバンドが大きく低波数 側ヘシフトし, 励起波長が長いほどDバンドの相対強度が 大きくなることが明らかにされてきた。さらに, $\mathrm{sp}^{3}$ 構造を 多く含むダイヤモンド状カーボン膜についても励起波長を 長くするほど低波数側のバンドの相対強度が大きくなるこ とが示されてきた21－23)。しかしながら，このようなラマ ンスペクトルの波長依存性について，その原因は必ずしも 良くわかっていないのが現状である。

最近筆者ら ${ }^{24)}$ はグラファイトのラマンスペクトルの励起 波長を紫外領域に拡大した測定を行い, 可視光励起による 測定結果と比較した。cw モードロックNd：YLFレーザー $(1053 \mathrm{~nm}, 76 \mathrm{MHz})$ の2倍波（526.5nm），およびそれを $\mathrm{BBO}$ 結晶で4倍波としたもの $(263.3 \mathrm{~nm})$ を光源として測 定したラマンスペクトルを Fig.7 に示す。 $1580 \mathrm{~cm}^{-1}$ 付近の Gバンドにはシフトが認められず，紫外光励起では 1360 $\mathrm{cm}^{-1}$ 付近のDバンドは消失したかのように見える。一方， 高波数側の 2nd-orderの領域においては, $2700 \mathrm{~cm}^{-1}$ 付近の
バンドが紫外光励起により大きく高波数側にシフトしてい る。263.3nm 励起の場合, 2nd-orderの領域はGC20では非 対称な単一ピークであるが, HOPG やBHOPG（ホウ素を ドープしたHOPG）では複雑な構造が認められる。2D, $\mathrm{D}+\mathrm{D}^{\prime}, 2 \mathrm{D}$ などの寄与が考えられるが, 実質的には $2 \mathrm{D}$ の状 態密度が高い。このことから, Dバンドの位置は1560 $1580 \mathrm{~cm}^{-1}$ 程度までシフトしていることとなり，ほとんど $\mathrm{G}$ バンドと重なっていることがわかる。Fig.8にGC20におけ るラマンバンドのピーク位置と励起エネルギーの関係を示 した。このような挙動は炭素材料の種類に大きくは依存せ ず, 可視光領域における波長依存性の延長上にあるが, 紫 外光励起ではラマンバンドのシフトが加速度的に大きくな ることがわかった。

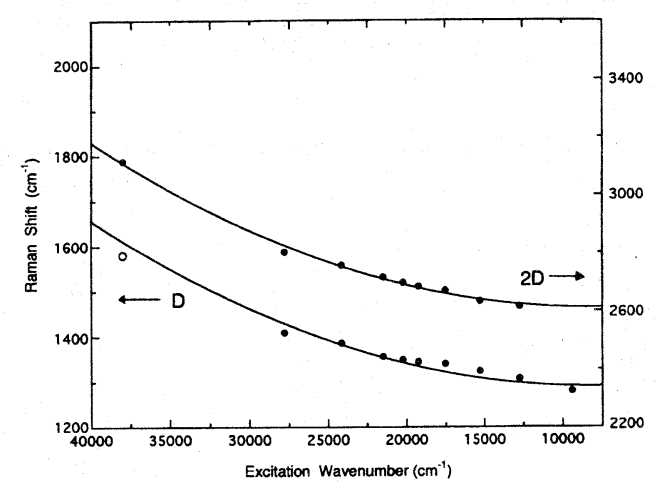

Fig.8 Peak frequency of $D$ and $2 D$ bands as a function of excitation energy.
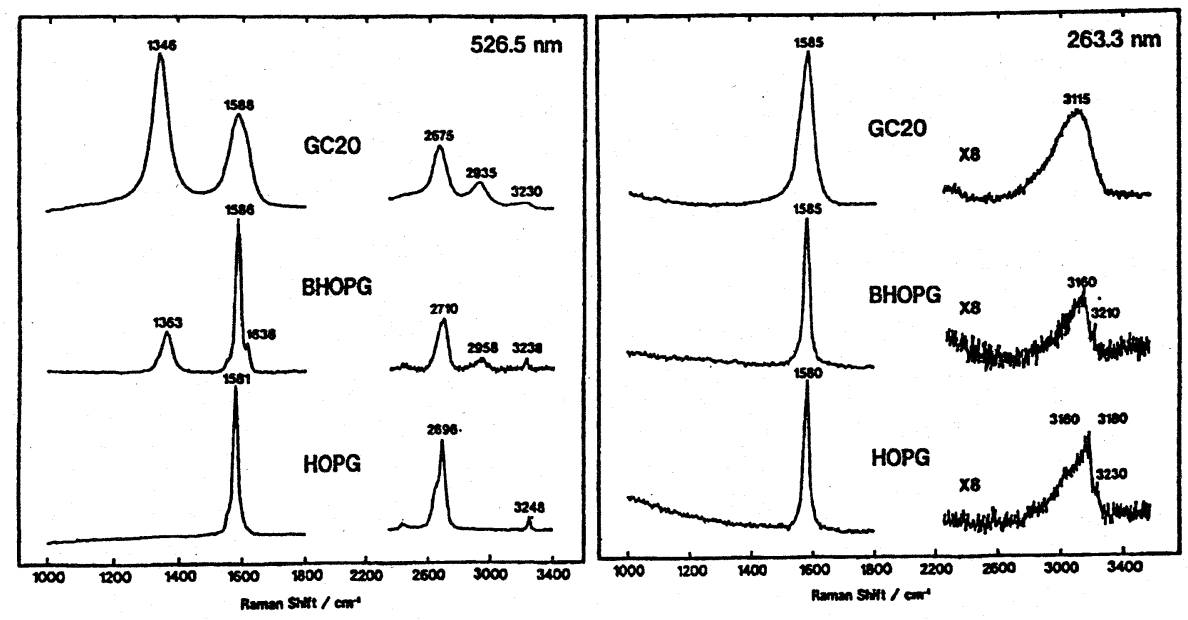

Fig.7 Raman spectra of HOPG, BHOPG and GC20 excited with 526.6 and $263.3 \mathrm{~nm}$. 


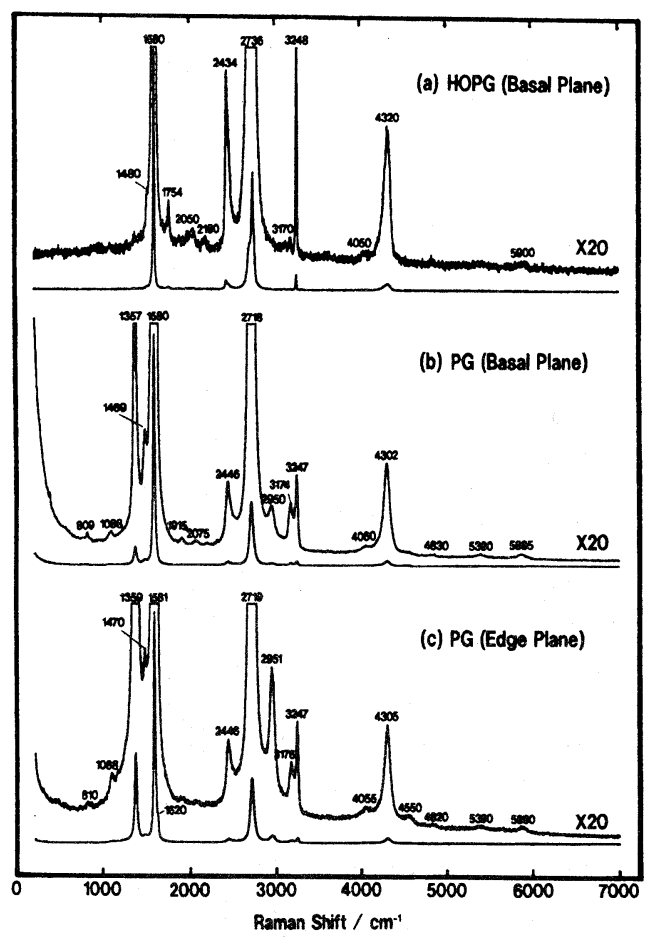

Fig.9 Raman spectra of HOPG basal plane, PG basal and edge planes with $488.0-\mathrm{nm}$ excitation.

\section{5. 高いSN 比による測定}

完全な構造を有するグラファイトは結晶の対称性から予 測されるバンド $\left(2 \mathrm{E}_{2 \mathrm{~g}}\right.$ ：1581および $\left.42 \mathrm{~cm}^{-1}\right)$ の他にフォ ノンの状態密度に起因すると考えられるバンド7) (2440, $\left.2730,3240 \mathrm{~cm}^{-1}\right)$ を示す。これらのバンドは互いに逆向き で大きさが等しい波数ベクトルを有する 2 つのフォノンの 結合によりラマン活性となった倍音モード7)とされている。 一方, グラファイト構造に乱れが生じると, 結晶の対称性 の崩れによって波数ベクトル選択則が成立しなくなり， $1360,1620 \mathrm{~cm}^{-1}$ に基本バンドが観測されるようになる。前 述のように，このようなフォノンの状態密度に起因するバ ンドの振動数はいろいろなモデルを用いて計算されている が, 計算結果は測定結果となかなか一致しないだけでなく, その中にはグラファイトのスペクトルにおいて見出されて いないものも存在する。そこで, グラファイトのラマンス ペクトルをできるだけ高いSN 比で測定し，これまでに認め られていないバンドの発見を試みた20)。励起波長として $\mathrm{Ar}+$ レーザーの514.5, 488.0 および457.9nmを用い, 波長 依存性の精密な測定も行った20)。

䢃開したHOPG およびPGのベーサル面, PG の研磨した
Table 1 The ratio of relative intensities of each band to the $G$ band between $P G$ edge and basal planes. $\left[\mathrm{I}_{\text {edge/hasal }}=\left(\mathrm{I}_{\Delta v} / \mathrm{I}_{\mathrm{G}}\right)_{\text {edge }} /\left(\mathrm{I}_{\Delta v} / \mathrm{I}_{\mathrm{G}}\right)_{\text {basal }}\right]$

\begin{tabular}{cc}
\hline $\begin{array}{c}\Delta v, \mathrm{~cm}^{-1} \\
\lambda=488.0 \mathrm{~nm}\end{array}$ & $\mathrm{I}_{\text {edgc/basel }}=\left(\mathrm{I}_{\Delta v} / \mathrm{I}_{\mathrm{G}}\right)$ edge/ $\left(\mathrm{I}_{\Delta v} / \mathrm{I}_{\mathrm{G}}\right)$ basel \\
\hline 810 & $\sim 0.87$ \\
1083 & 2.00 \\
1357 & 5.26 \\
1469 & $\sim 0.90$ \\
1620 & $\infty$ \\
2446 & 1.14 \\
2718 & 1.07 \\
2950 & 4.09 \\
3174 & 1.22 \\
3247 & 1.29 \\
4044 & 2.00 \\
4302 & 1.15 \\
4550 & $\infty$ \\
4830 & $\sim 1.12$ \\
5390 & 1.01 \\
5885 & 1.09 \\
\hline
\end{tabular}

エッジ面のラマンスペクトル（励起波長：488.0nm）を Fig.9に示す20)。7000 $\mathrm{cm}^{-1}$ までの測定により高次の領域に 多数のバンドが認められるが, それのみならず1次の領域 にもこれまでに報告されたことのない新たなバンドが見出 される。これらのバンドの帰属, 特性の把握を行うために, 以下の2つの解析を行った。

(1)各ラマンバンドの $G$ バンドとのピーク高さの比 $\left(\mathrm{I}_{\Delta v} / \mathrm{I}_{\mathrm{G}}\right)$ をPGのエッジ面とベーサル面について比較し, $\mathrm{I}_{\text {edge/basal }}=$ $\left(\mathrm{I}_{\Delta v} / \mathrm{I}_{\mathrm{G}}\right)_{\text {edge }} /\left(\mathrm{I}_{\Delta v} / \mathrm{I}_{\mathrm{G}}\right)_{\text {basal }}$ をTable 1 に示した。 $\mathrm{I}_{\text {edge/basal }}$ は, $1360,1620 \mathrm{~cm}^{-1}$ などのように, 波数べクトルの選択則 に従わないバンドについては大きな值をとることから，2D や2D'のような複数の波数べクトルの組み合わせによって 選択則にしたがう倍音や結合音との区別が可能となる。

(2)各ラマンバンドの励起波長依存性を調べると , バンドに よってシフトの方や大きさが異なっていることがわかる。 また, 当然のこととも言えるが, 倍音や結合音およびさら に高次のバンドのシフトはそれぞれの構成成分のシフトの 和になるという法則も成立することがわかる。PGについて のラマンバンドの励起波長依存性およびシフトの方向およ び大きさをTable 2 にまとめた20)。

以上のような解析によって各ラマンバンドの帰属を行っ た結果をTable 2 に合わせて示した20)。2446 $\mathrm{cm}^{-1}$ のバンド は2D や $2 \mathrm{D}^{\prime}$ バンドと同様の倍音で $2 \mathrm{D} "$ バンド7) と呼ばれて きたが，基本モードの位置に相当する $1223 \mathrm{~cm}^{-1}$ 付近には， SN比の高い測定においてもラマンバンドは認められない。 
Table 2 Peak positions, the magnitude of the band shifts and the assignments.

\begin{tabular}{|c|c|c|c|c|c|}
\hline $\begin{array}{c}\text { HOPG } \\
\lambda=488.0 \mathrm{~nm}\end{array}$ & $\lambda=457.9 \mathrm{~nm}$ & $\begin{array}{c}\Delta v, \mathrm{~cm}^{-1} \\
P G \\
\lambda=488.0 \mathrm{~nm}\end{array}$ & $\lambda=514.5 \mathrm{~nm}$ & $\begin{array}{c}\delta(\Delta v) / \delta \lambda \\
\mathrm{cm}^{-1 / n m}\end{array}$ & Assgnt. \\
\hline & $\sim 803^{*}$ & $\sim 810^{*}$ & $\sim 820^{*}$ & 0.30 & \\
\hline & $1071^{*}$ & $1083^{*}$ & $1094^{*}$ & 0.41 & \\
\hline & 1365 & 1357 & 1352 & -0.23 & $\mathrm{D}$ \\
\hline$\sim 1480$ & 1455 & 1469 & 1480 & 0.44 & $?$ \\
\hline \multirow[t]{2}{*}{1580} & 1580 & 1580 & 1580 & 0 & G \\
\hline & $1623^{*}$ & $1621^{*}$ & $1622 *$ & $\sim 0$ & $\mathrm{D}^{\prime}$ \\
\hline \multirow[t]{2}{*}{1754} & & & & & $?$ \\
\hline & $\sim 1927$ & 1915 & $\sim 1890$ & -0.65 & $?$ \\
\hline 2050 & & 2075 & 2040 & -1.32 & $?$ \\
\hline 2180 & & $\sim 2184$ & $\sim 2184$ & $\sim 0$ & $810+D$ \\
\hline 2434 & $2440^{*}$ & $2446^{*}$ & $2451^{*}$ & 0.19 & $1083+\mathrm{D}$ \\
\hline \multirow[t]{2}{*}{2736} & 2732 & 2718 & 2705 & -0.48 & $2 \mathrm{D}$ \\
\hline & 2955 & 2950 & 2945 & -0.18 & $\mathrm{D}+\mathrm{G}$ \\
\hline 3170 & 3179 & 3174 & 3176 & $\sim 0$ & $2 \mathrm{G}$ \\
\hline 3248 & 3246 & 3247 & 3244 & $\sim 0$ & $2 D^{\prime}$ \\
\hline 4050 & $\sim 4055^{*}$ & $\sim 4044^{*}$ & $\sim 4031^{*}$ & -0.42 & $3 \mathrm{D} ?$ \\
\hline \multirow[t]{2}{*}{4320} & 4318 & 4302 & 4288 & -0.53 & $2 \mathrm{D}+\mathrm{G}$ \\
\hline & $4558^{*}$ & $4551^{*}$ & $4544 *$ & -0.25 & $\mathrm{D}+2 \mathrm{G}$ \\
\hline$\sim 4820$ & $\sim 4830$ & $\sim 4830$ & $\sim 4830$ & $\sim 0$ & $2 D^{\prime}+G$ \\
\hline$\sim 5400$ & 5415 & 5390 & 5370 & -0.80 & 4D \\
\hline$\sim 5900$ & 5900 & 5885 & 5870 & -0.53 & $2 \mathrm{D}+2 \mathrm{G}$ \\
\hline
\end{tabular}

また，いくつかの帰属不明なバンド $(1480,1754,1915$, 2075, 2184cm-1 など) が存在するが, これらのバンドも励 起波長依存性を示すことから，表面の酸化種や久陥などに よるもの19)ではなく, グラファイトの本質的な振動モード 20)であると考えられる。

\section{6. 炭素材料の微細構造のキャラクタリゼーション25)}

炭素材料の黑鉛化度の評価には, Gバンドの半值幅 $\left(\Delta \mathrm{v}_{1580}\right)$ および2つのラマンバンドのピーク高さ比 $\left(\mathrm{I}_{1360} / \mathrm{I}_{1580}\right)$ がしばしば用いられるが, これらのパラメータ はこれまで述べてきたように，

$\Delta v_{1580} \quad$ : 黒鉛化度（ローカルなグラファイト構造の完 全性)

$\mathrm{I}_{1360} / \mathrm{I}_{1580}$ : 黒鉛化度およびグラファイト結晶表面のエッ ジ，結晶境界の比率

を反映している12)。これら2つのパラメータを縦軸と横軸 にとったマップを作成することにより，さまざまな炭素材 料の微細構造のキャラクタリゼーションを行うことができ る。典型的な炭素材料の微細構造のイメージとマップの関

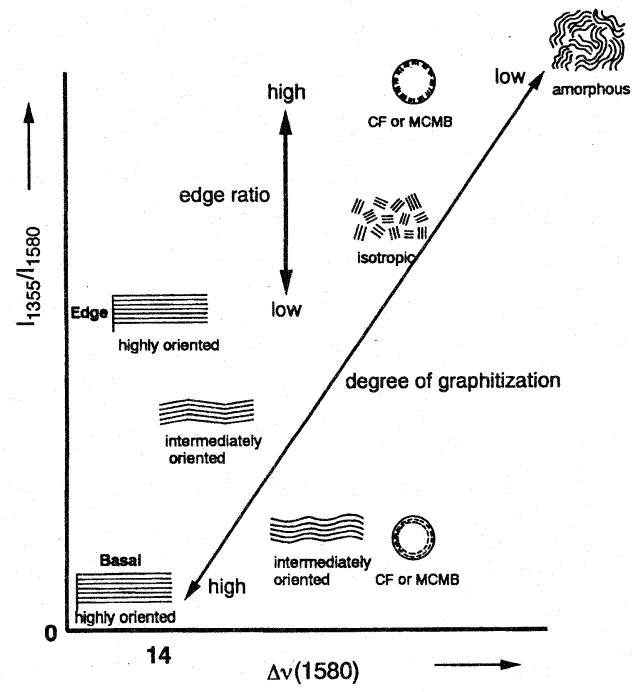

Fig.10 Structural image for a variety of carbon and graphite materials on the map between $\Delta v_{1580}$ and $\mathrm{I}_{1360} / \mathrm{I}_{1580}$. 


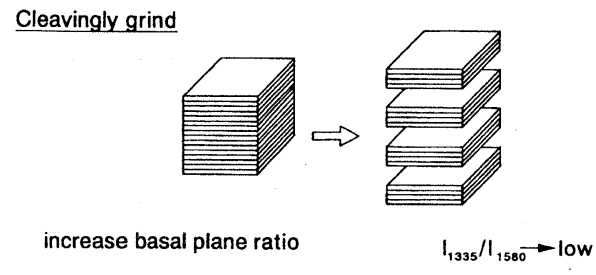

Cuttingly grind

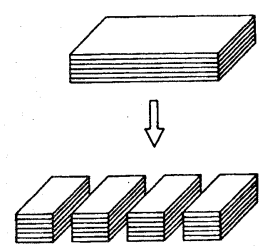

increase edge plane ratio

$\mathrm{I}_{1335} / \mathrm{I}_{1580} \rightarrow$ high

Structural degradation by grinding

decrease the degree of graphitization $\Delta v(1580) \rightarrow$ high

Fig.11 Schematic illustration and Raman spectral change for cleavingly grind and cuttingly grind.

係をFig.10に示した。HOPGのベーサル面においては $\mathrm{I}_{1360} / \mathrm{I}_{1580}=0$ であり, $\Delta v_{1580}$ は $14 \mathrm{~cm}^{-1}$ 程度である。通常の 場合はいわゆる黒鉛化度が低下するにつれて，2つのパラメ ータはいずれも大きくなり, マップ上を左下から右上に向 かって移動することになる。一方, HOPGのエッジ面では $\mathrm{I}_{1360} / \mathrm{I}_{1580}$ が有限の值をとるようになるが, $\Delta \mathrm{v}_{1580}$ はべーサ ル面と同様シャープなままである。このように, 同一の材 料でエッジや結晶境界の割合が増す場合はマップ上を下か ら上に移動する。

中配向のものとして2種示したが，（A）黒鉛化度は高い が結晶境界の多いものと（B）黑鉛化度は低めであるが明確 な結晶境界の少ないものをマップ上で識別することが可能 である。また，炭素繊維やMCMB の微細構造（オニオン， ラジアル等）を評価できることも非常に興味深い。ただし， ラマンスペクトルで評価できるのはあくまでも表面数 10 $\mathrm{nm}$ 程度の構造についてであり, TEM やSEM 観察, X 線回 折などの結果との比較には注意が必要である。

\section{7. リチウム二次電池用グラファイト粉末の評価 25$)$ - 27)}

グラファイト粉末のラマンスペクトルはベーサル面とエ ッジ面のラマンスペクトルの重ね合わせとして考えること ができる。原料, 製法や焼成温度の違いによって, 粉末表面 におけるべーサル面とエッジ面の比率は大きく異なる。ま

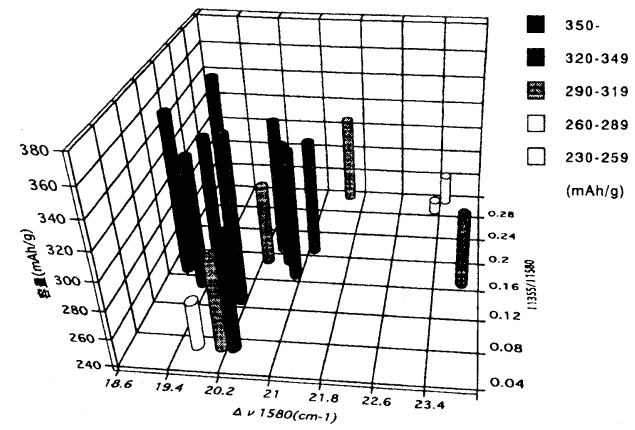

Fig.12 The relationship between $\Delta v_{1580}, I_{1360} / I_{1580}$ and the capacity.

た，まったく同一のグラファイトであっても，これを粉砕 する場合, 粉砕方法によってベーサル面とエッジ面の表面 積比率が異なり, ラマンスペクトルも変化する。幦開的 (cleavingly grind) および割断的 (cuttingly grind) な2種 の極端な粉砕の場合を模式的にFig.11に示す。また, 粉砕 によって粉末の構造に乱れを生ずる場合は $\Delta v_{1580}$ が大きく なるため, 容易に判定が可能である。

さまざまな黒鉛粉末のラマンスペクトルとそれを負極材 料として用いたリチウム二次電池の容量との関係を Fig.12 に示す。 $\Delta v_{1580}$ が小さく, $\mathrm{I}_{1360} / \mathrm{I}_{1580}$ が大きいほど, 電池容量 は高くなる傾向にあり, 容量の観点からは黒鉛化度が高く, 表面にエッジの出たものが望ましいことがわかる。

\section{8. 顕微ラマンの応用-イオン注入した炭素䄉維の分 析-28)}

炭素繊維にイオンを注入することによって，炭素繊維の 強度が大きく改善される。炭素繊維の直径は約 $7 \mu \mathrm{m}$ であ り，このような微小な部分の測定も光学顕微鏡を試料室と した顕微ラマンを用いることによって可能となる。しかし ながら, 顕微ラマンにおけるビーム径は約 $1 \mu \mathrm{m}$ であること から, 通常の断面について測定したのでは深さ分解能とし て物足りない。炭素纎維のようにレーザー光の吸収が大き く, 測定深さの浅い試料の場合は, 傾斜研磨を行うことに よって深さ分解能を大幅に向上させることができる。通常 の垂直断面では深さ分解能はレーザー光のビーム径により 支配され，高々 $1 \mu \mathrm{m}$ である。これに対し，傾斜研磨を行う と, 深さ分解能は傾斜角 $(\alpha)$ に応じて $(\sin \alpha) \mu \mathrm{m}$ とな り，たとえば傾斜角 $3^{\circ}$ で深さ分解能を $50 \mathrm{~nm}$ 程度とするこ とができる。B+イオンを加速電圧 $150 \mathrm{kV}$ で $1 \times 10^{16}$ ions $/ \mathrm{cm}^{2}$ 注入した炭素繊維の表面と中心部のラマンスペク トルをFig.13に示す。イオン注入による非晶化が生じた部 分ではラマンバンドの半值幅が大きくなっている。イオン 


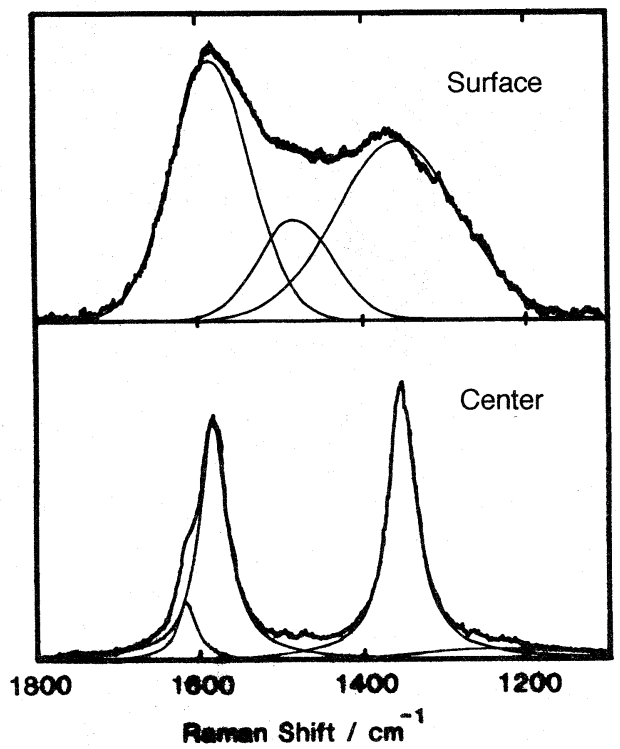

Fig.13 Raman spectra of $\mathrm{B}^{+}$implanted carbon fiber. (Acceleration voltage : $150 \mathrm{kV}$, Dose $: 1 \times 10^{16}$ ions $/ \mathrm{cm}^{2}$ )

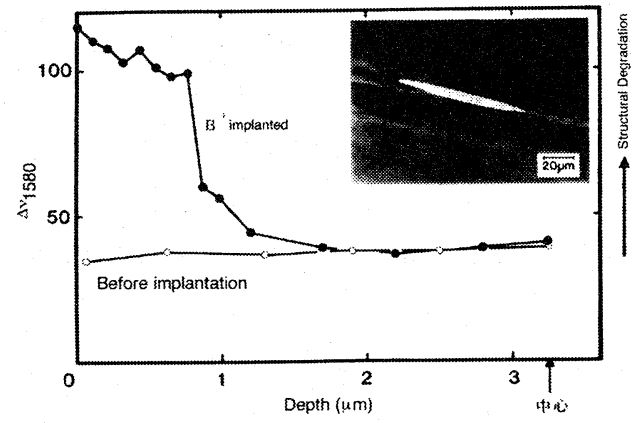

Fig.14 Depth profile for structural degradation by $\mathrm{B}^{+}$ implantation.

注入前後の炭素繊維について, $1580 \mathrm{~cm}^{-1}$ 付近のラマンバン ドの半值幅を炭素繊維の深さに対してプロットすることに より, Fig.14に示すようなイオン注入による構造変化のデ プスプロファイルを求めることができる。これより, 非晶 化層の厚さは $1 \mu \mathrm{m}$ 程度であることがわかり, これは注入条 件から計算されるB+イオンの飛程と良く一致している。

\section{9. まとめおよび今後の課題}

本稿で述べたことを項目別にまとめ, 未解決の問題の整 理し，また今後の課題についての展望を行った。

（1）励起波長依存性について
これまでに報告されてきた16)，17) D バンドやその倍音の みでなく，多くのバンドが近赤外から紫外領域にわたる広 い範用で励起波長によってシフトすることが確認された。 シフトの方向や大さはそれぞれのバンドによって異なる が，倍音や結合音のシフトはその構成成分のシフトの和に なる。励起波長依存性の挙動は炭素材料の種類に大きくは 依存せず，HOPGからダイヤモンド状カーボン膜に至るま で類似した挙動を示す。このことから, 波長依存性の原因 として容易に考えつく, 以下の 2 つ考え方では説明が困 難である。

(1)励起波長依存性を示す例として有名なポリアセチレンの ように，共役系の長さ（大きさ）の異なる成分の混合物で あり，励起波長に応じて異なる成分が共鳴ラマン効果を示 す。

(2)試料の表面と内部で構造が異なっており，励起波長によ って測定深さが変化するため, ラマンスペクトルが変化す る。

このような励起波長依存性の挙動は非共鳴のラマン散乱 では理解しにくく，炭素材料における共鳴ラマンに特有な 現象のように思われるが, 他に例がなく従来の理論では説 明が困難なように思われる。黒鉛化度の異なる炭素材料か らダイヤモンド状カーボン膜まで統一した説明の可能なメ カニズムを考える必要があるが, これらの電子状態は大き く異なっており，その共鳴ラマン効果も大きく異なると考 えられることから, まことに不思議な現象と言わざるを得 ない。

(2) グラファイトのラマンスペクトルの帰属について

SN 比を上げた精密な測定によって, HOPG やPGにおい て1次および高次の領域に従来見出されていないバンドを 多数見出した。(1)ベーサル面とエッジ面のラマンバンドの 強度の比較, (2)上述の励起波長依存性, (3)倍音, 結合音の組 み合わせ，などを考え合わせることによって，多くのバン ドの帰属を行うことができた。しかしながら， $2446 \mathrm{~cm}^{-1}$ の (2D") バンドの基本モードの位置に相当する $1223 \mathrm{~cm}^{-1}$ 付近 にはラマンバンドは認められない。また, 結晶構造からも 予測されず州属の不明確なバンド $(810,1083,1480,1754$, $1915,2075,2184 \mathrm{~cm}^{-1}$ など）が存在する。このようにHOPG のラマンスペクトルについてですらまだまだわからない点 が多く残されている。これらの解明のためには, 精度を上 げた振動状態密度の計算を行い, 実験結果と比較してゆく ことか望まれる。

(3) 炭素材料の構造の評価

炭素材料のラマンスペクトルにおいては, R 值 $\left(\mathrm{I}_{1360} / \mathrm{I}_{1580}\right)$ による黑鉛化度の評価が極めて一般的に用いら れているが，現状におけるいくつかの問題点を挙げた。一 方, $\mathrm{R}$ 值のみがラマンスペクトルの解析方法ということで 
はなく，ラマンスペクトルの特徵を良く理解した適用によ って, より詳細な構造の評価が可能となる。特にラマンバ ンドの半值幅 $\left(\Delta v_{1580}\right)$ を求め, これと $\mathrm{I}_{1360} / \mathrm{I}_{1580}$ ことのマ ップを描くことによって, さまざまな炭素材料の微細構造 のキャラクタリゼーションが可能となる。ここでは, $\mathrm{Li}$ 二 次電池の負極用グラファイト系粉末への応用例を示し, 電 池の容量とグラファイト系粉末の構造の関係を明らかにし たが，さまざまな系への応用が可能である。

\section{(4) アモルファスカーボンの評価}

炭素繊維や電池用炭素材料などアモルファス性の炭素材 料はX線回折やTEMによる評価も困難であり，ラマンスペ クトルによる評価が望まれるところである。紙数の関係で 十分な記述ができなかったが，これらのラマンスペクトル は出発物質などさまざまな要因に依存して極めて複雑な挙 動を示すことから, R 值 $\left(\mathrm{I}_{1360} / \mathrm{I}_{1580}\right)$ やバンドの半值幅など のパラメータによってラマンスペクトルの形状を比較する ことが困難である。しかしながら, 最近の装置の進歩によ ってかなり SN 比の高いラマンスペクトルが測定できるよ うになってきた。スペクトル形状を正確に解析することに よって, 詳細な構造情報が得られることが期待され，今後 はこの方向に研究が進んでゆくことが期待される。 $\mathrm{Li}$ 二次 電池用のハードカーボンの構造と電池特性の関係の解明, アモルファスカーボンに存在すると言われる 5 員環や7員環 の構造解析29) など, 興味深いテーマが待ち受けている。

\section{文献}

1）中溝 実, 炭素 1977 [No.90] 105-113.

2) K.K. Mani and R. Ramani, Phys. Stat. Sol., B61 (1974) 659-667.

3) R.J. Nemanich, G. Lucovsky and S.A. Solin, in Proc. Of the Int'l. Conf. On Lattice Dynamics, M. Balkanski, ed., p.619 (Flammarion, Paris, 1978).

4) R.J. Nemanich, G. Lucovsky and S.A. Solin, Solid State Commun. 23 (1977) 417-420.

5) F. Tuinstra and J.L. Koenig, J. Chem. Phys. 35 (1970) 1126-1130.

6) F. Tuinstra and J.L. Koenig, J. Composite mater. 4 (1970) 492-499.

7) R.J. Nemanich and S.A. Solin, Phys. Rev. B20 (1979) 392-401.

8) P. Lespade, R. Al-Jishi and M.S. Dresselhaus, Carbon, 20 (1982) 427-431.

9) R. Al-Jishi and G. Dresselhaus, Phys. Rev. B26 (1982) 4514-4518.

10) M. Nakamizo, R. Kammereck and P.L. Walker, Jr., Carbon, 12 (1974) 259-267.
11) Sadtler Standard Spectra, Raman Spectra, 3556.

12) G. Katagiri and N. Takeda, International Conference on Coals and Organic Petrology, Fukuoka 1996.11.14-16.

13) G. Katagiri, H. Ishida and A. Ishitani, Carbon 26 (1988) 565-571.

14) R. Vidano and D.B. Fischbach, J. Am. Ceram. Soc., 61 (1978) 13-17.

15) M. Nakamizo and K. Tamai, Carbon 22 (1984) 197-198; 中溝 実, 玉井桂子, 炭素1984 [No.117] 94-97.

16) Y. Wang, D.C. Alsmeyer, and R.L. McCreery, Chem. Mater. 2 (1990) 557-563.

17) R.P. Vidano, D.B. Fischbach, L.J. Willis, and T.M. Loehr, Solid State Commun. 39 (1981) 341-344.

18) A.V. Baranov, A.N. Bekhterev, Y.S. Bobovich, and V.I. Petrov, Opt. Spectrosc. (USSR) 62 (1987) 612-616.

19) T.P. Mernagh, R.P. Cooney, and R.A. Johnson, Carbon, 22 (1984) 39-42.

20) Y. Kawashima and G. Katagiri, Phys. Rev. B52 （1995）10053-10059; 川島 康，片桐 元，第22回 炭素材料学会年会, 長崎, 1995.11.30-12.2 2C05.

21) M. Ramsteiner and J. Wagner, Appl. Phys. Lett., 51 (1987) 1355-1357.

22) M. Yoshikawa, G. Katagiri, H. Ishida, A. Ishitani and T. Akamatsu, J. Appl. Phys., 64 (1988) 64646468.

23) J. Wagner, M. Ramsteiner, Ch. Wild and P. Koidl, Phys. Rev., B40 (1989) 1817-1824.

24）片桐 元，R.M. McCreery and T.L. Gustafson,, 第 22 回炭素材料学会年会, 長崎 1995.11.30-12.2 2C04.

25）片桐 元, 岩永 光, 石田英之, 永田博美, 新田芳明, 第35 回電池討論会, 名古屋 1994.11.14-16 2B06.

26）片桐 元, 石田英之, 第 36 回電池討論会, 京都 1995.9.12-14 1B15.

27) G. Katagiri, H. Ishida and Y. Nitta, 8th International Meeting on Lithium Batteries, nagoya 1996.6.16-21 IA39.

28) Y. Matsuhisa, M. Washiyama, T. Hiramatsu, H. Fujino and G. Katagiri, 20th Biennial Conference on Carbon, Extended Abstracts, Santa Barbara 1991, p. 226.

29）小鍛冶和己, 原 和美, 大谷朝男, 山田能生, 白石 稔, 第21 回炭素材料学会年会, 東京 1994.12.7-9 $1 \mathrm{~B} 09$. 